\title{
Strategic Analysis on the Construction of Class Culture in Colleges and Universities
}

\author{
Li Zhang* \\ Jiangxi University of Technology, Nanchang 330098, Jiangxi Province, China \\ *Corresponding author: Li Zhang, my15010923357@163.com
}

\begin{abstract}
In schools, the basic unit is a class, and each class is composed of different groups of students. In order to strengthen college education and improve the quality of education, it is necessary to conduct a comprehensive analysis and research on classes. A variety of organizations of college students constitute classes. As the manifestation of these organizations, classes carry out ideological and political education for students. In order to promote students' progress and development, an excellent class culture should be established. On that premise, it is necessary to strengthen ideological and political education for students, ensure more coordination between education and culture, as well as improve students' cultural literacy, management system, and the safety of campus life. This study focuses on the strategy of building class culture in colleges and universities, hoping that relevant staffs may be able to use this as a reference.
\end{abstract}

Keywords: Classes in colleges and universities; Cultural construction; Strategy analysis

Publication date: October 2021; Online publication: October 29, 2021

\section{Introduction}

A class is not only the most basic organization, but also an important part of a university. As the vitality of the country, college students are the future of the country. Therefore, the construction of class culture is also related to the rise and fall of the country. In the new era, in order to build campus culture, the construction of class culture needs to be strengthened. In the process of carrying out ideological and political education for students, universities should acknowledge the importance of strengthening the construction of class culture. Analyzing the construction of class culture in universities is conducive to promote the development of ideological and political education. Under the new situation, it can also improve the scientific level of ideological and political education in universities, adhere to the notion of people-oriented, live in harmony with teachers and students, as well as achieve the goal of class culture construction ${ }^{[1]}$.

\section{Overview of class culture construction}

Within schools, classes are the most basic constituent units. In order to ensure the civilized development of colleges and universities, healthy classes are necessary. Therefore, the establishment of class culture is the key to the construction of campus culture. The content of cultural construction is abstract, but it affects people's attitude and values toward life. If everyone accepts different cultures, their values would be different along with their actions. Therefore, through the construction of class culture, the knowledge, skills, and ideas related to teaching methods can be conveyed to students. As the mainstream culture of the class, class culture will affect the material environment of the class and the values of the whole class. The establishment of class culture plays an important role in the construction of the overall campus culture. In an excellent class environment, a strong learning environment would naturally be formed ${ }^{[2]}$. In this environment, students would be encouraged to study hard, explore more, seek truths from knowledge, be 
positive and enterprising, maintain harmony with their teachers and among other students, as well as actively improve their comprehensive quality.

\section{Practical significance of strengthening the construction of class culture in colleges and universities}

\subsection{Reflect the needs of advanced culture and carry forward the theme of the times}

In order to ensure that ideological and political education in colleges and universities meets the expectations, it is important to make rational use of educational skills and take effective educational methods to help students improve their political thinking, promote the development of educational work, and play the role of political education. In ideological and political education, it is also very important to strengthen the construction of class culture, so that the lessons are not only livelier, but also easier for college students to accept. This in turn would promote college students to obtain the relevant knowledge and grow imperceptibly, thus achieving good results ${ }^{[3]}$.

\subsection{A necessity to further strengthen the construction of class culture}

Class construction affects the individual socialization of college students. Relevant psychological research has shown that through the continuous construction of class culture, college students are able to set correct values for social needs. Gradually, it has become the main task of ideological and political education in colleges and universities. From the value orientation of teaching culture in universities, the common values of teachers and students are the deepest embodiment of the classroom spirit. It plays a very important role in the behavior and psychological state of teachers and students. In terms of psychology, culture can be regarded as a unified psychological process of group formation. At this level, the specific living environment is determined by the class culture, and the ideology and politics of the university would play a role in the development of college students. The construction of class culture is conducive to laying a solid foundation for achieving the expected goals. Therefore, it is very important to strengthen the construction of class culture in colleges and universities.

\subsection{An inevitable requirement to guide students' value orientation}

In regard to ideological and political education for college students, the role of class culture is significant. For college students, their value orientation is not only affected by the nature of the teaching experience, but also the teaching objectives. If it is possible to reasonably establish class culture, the moral quality of students would be improved throughout the whole class. Firstly, in the construction of class culture, it can play an exemplary role and greatly promote the ideological and moral education of college students. Class culture in universities is based on the code of conduct and values. It has become a model for moral education to a certain extent. Paying attention to the moral education of college students is not a strict requirement, but a reasonable limit in the hearts of students. Under the influence of class culture, students must have clear values. They would then be more active in self-improvement, give full play to their self-value, and promote social development. In universities, some codes of conduct do not only include written moral norms, but also non-written moral norms. College students can set their own personality examples in class culture. With the gradual formation of teaching culture, these examples have been recognized by students. Class leaders and teachers need to rely on their own charms to establish a good class environment, which would help college students reveal themselves better. Secondly, as class culture is relatively hidden, it helps in the moral education of college students and improve the quality of the education. One of the greatest characteristics of moral education is the integration of emotion, knowledge, intention, and behavior of people with special education. Educated people need moral education in regard to their subjective consciousness in order to achieve more effective results ${ }^{[4]}$. 


\subsection{Objective requirements to promote the universal development of college students}

Class culture is an important component of campus culture. In order to build campus culture, class culture should be first established. Through the construction of class culture, the overall class style and teaching quality can be improved. In order to establish a teaching culture, a teaching style should be first established. A good class environment is the first step in the construction of class culture. The main content of class teaching psychology, goal, and class style decision should be the process of self-education and selfmanagement. A good teaching style and teaching spirit would help cultivate civilized habits and enhance class cohesion. This would in turn help teachers achieve the goal of class culture construction as well as urge students to be strict with themselves and pay attention to their civilization and hygiene. If there is no class culture, most classes will be "dirty, messy, and bad." After establishing a good class style, the enthusiasm of each college student should be mobilized and they should be encouraged to devote themselves to other tasks pertaining class groups, so that the construction of class culture will flourish. In addition, the establishment of class culture also needs the creation of a learning style. The composition of learning style is mainly aimed at students' clear learning motivation, which can enhance learning awareness and enthusiasm as well as guide students in self-management. It is also important to make learning plans as well as arrange work and rest time, so that students can develop good learning habits, while teachers can provide learning guidance in time. This would improve the academic performance of the whole class, adjust the development level of various disciplines, and ensure the overall progress of students ${ }^{[5]}$.

\section{Strategic analysis on the construction of class culture in colleges and universities}

\subsection{Strengthening the leading role of the school}

School leaders play an important role in the development and construction of schools. Therefore, leaders should also be aware of the importance of class culture, actively participate in the construction of class culture, provide scientific and effective planning and arrangement for the construction, improve relevant rules and systems, lay proper institutional foundation for the construction of class culture, constantly improve the school management concept, grasp the characteristics of the school, adapt to the characteristics of the times in the process of school management, take charge of the whole campus, create a cultural environment, provide spiritual and cultural basis to establish teaching culture, correct teaching evaluation and incentive measures, as well as further improve quantitative indicators. In addition, they also need to actively promote excellent classroom culture in various ways to create a good learning environment in order to promote the learning of advance culture.

\subsection{Making full use of the leading role of university counselors}

As lecturers who maintain the relationship between schools and students, it is necessary to have an accurate understanding and positioning of the establishment of class culture. The most important role of counselors is ideological guidance. Counselors should set good examples for students by being self-disciplined, elegant yet rigorous, civilized, and polite. They should plan to establish a good class culture, formulate relevant solutions to class problems, and encourage class leaders to implement them in detail. In many universities, lecturers are dual subject teachers. In addition to teaching basic theoretical knowledge, they also help to establish a correct world outlook and constantly improve students' views.

\subsection{Paying attention to the main links of building class culture}

\subsubsection{Teaching system as the foundation}

Nothing can be accomplished without norms or standards. In addition to relying on the conscious self- 
control of most students, a good class group is essential for a class system. Therefore, to improve the level of class culture, the prerequisite is to improve the class management system. Tutors should fully consider the relevant systems and requirements of the school in combination with the specific development of the class, guide all class members to abide by the class rules and regulations in terms of academic fashion, ideology, and discipline, as well as ensure that all class members adhere to the basic behavior guidelines and the "bottom line," which is the basis for instructors to quantitatively evaluate the class. In addition, the class collective should establish a unified goal, and in the process of achieving this goal, counselors and monitors should encourage and support all members to ensure the realization of the goal.

\subsubsection{Construction of class style as the key}

In the construction of teaching culture, teaching style is particularly important. University level research plays a decisive role in how students would step into the society in the future. At university level, learning is the main task of students. At the same time, it is necessary to form good learning attitudes, establish good learning thinking and concepts, master proper learning methods, form good learning habits, and determine learning objectives. It is important to ensure that students have a learning direction and motivation as the primary task of establishing teaching style. In order to establish a more reasonable teaching method, first of all, for all college students, their ideological understanding should be strengthened. Secondly, the role of the class system should be fully exercised, and appropriate fines should be imposed on individuals with disciplinary violations according to the rules and regulations as well as the teaching system. These include absenteeism, being late, failing to complete homework, fighting, etc. In short, every effort would create a good classroom environment, and every class member would be affected without interference. Over time, opportunities form a lasting spiritual motivation.

\subsubsection{Strengthening thematic activities}

Thematic activities are the best way to strengthen the construction of class culture. For example, a theme can be designed every two weeks. These themes may include themes which are related to students' growth, such as "Safety Around Me." When learning, it should closely fit with international and domestic topics related to current affairs and politics; then, it would be conducive in expanding students' knowledge and displaying their language skills. In addition, in line with the development of teaching culture and evaluation activities carried out by the school or department, a cultural wall can be created by putting up famous proverbs or growth history of famous companies on the corridor of the lecture hall or the wall of the classroom, so that students can fully experience the environment of class culture, which would imperceptibly influence the students. Interesting practical thematic activities can also be carried out, such as tug of war, dumpling making, charity activities, and cultural night. By carrying out various thematic activities, it is possible to promote unity, diligence, and spirit, so as to enhance the unity of the class and promote the healthy growth of students through the influence of good class culture.

\subsection{Emphasizing the leading position of students and mobilizing students' enthusiasm}

In order to establish class culture, it is vital to first ensure the main status of students and show the link with the example of class leaders. In the process of class culture management, begin from the work requirements of the head teacher and select students with ability and political integrity according to the actual needs of students to become good cadres, so as to help the construction and development of class culture. After selecting appropriate cadres, it is also necessary to strengthen education and training. It is not only necessary to conduct regular and organized training, but also targeted class management training. In addition to theoretical training, counselors should emphasize on guiding, motivating, encouraging class teachers to 
take responsibility, actively helping students to solve daily difficulties, effectively promoting the establishment of class culture, and enabling them to play the most systematic role in the core role model as soon as possible. In addition to the exemplary leadership role of class management cadres, the role of other class members cannot be neglected. Each member must give full play to their strengths and make use of their special talents. For example, the sports, music, or unique learning methods add vitality to the construction of class culture; thus, these talented students should be encouraged to participate in different activities at different times to achieve honors. Following that, introverted students would begin to feel the enthusiasm of the class. Teachers should then pay attention to them, cooperate with other students to provide a helping hand, as well as guide and care for them, so as to help them overcome difficulties, make positive progress, and ensure that all members of the class are healthy and happy.

\subsection{Paying attention to innovating the form of class culture construction}

Class culture can be established by expanding new fields and channels. For example, divide a mutual aid class into different groups in a systematic manner based on gender, learning abilities, hobbies, personalities, language skills, hometown, and so on. Thereafter, encourage every group member to engage in activities that require mutual assistance in order for the stronger ones to help those with poorer grades. This form is beneficial to all team members. For students with excellent grades, they would further develop. For students with poor grades, they would be able to improve their learning skills and effect. In addition, students can also make full use of their winter vacation and summer vacation. By filling in some local popular questionnaires, students may gain deeper insights into social problems and enrich their social experience. Moreover, it can also give full play to the role of information technology, establish a website specifically for the class, formulate relevant online class rules and regulations, communicate with students regularly, as well as improve the network culture platform. The construction of class culture cannot be achieved overnight; instead, it needs to be done step by step. With the development of society and the progress of the times, social competitiveness is becoming stronger, the demand for talents is increasing, and the requirements are raising. Therefore, cultural construction must also keep up with the trend of the times, make full use of the concept of scientific development, promote advanced technology to the society, which has become a powerful guarantee, give full play to the role of internet platforms, as well as promote the construction and development of class culture in colleges and universities.

\section{Conclusion}

The construction of class culture in universities requires long-term practice, continuous accumulation, and development. There is no fixed and unified model in the process of efficient class culture construction. It is necessary to keep pace with the times according to the actual situation of the class, constantly look for new methods and models, respond to the requirements of cultural reform, grasp the mainstream of the values of the times, establish a distinctive teaching culture, as well as ensure the comprehensiveness in the construction of class culture in colleges and universities.

\section{Disclosure statement}

The author declares that there is no conflict of interest.

\section{References}

[1] Wu SW, 2013, Research on Strategies for Strengthening Class Culture Construction in Colleges and Universities under the New Situation. Education and Vocation, (27): 50-51. 
[2] Zhang YJ, 2016, Research on Practical Strategies of Class Culture Construction. Northeast Normal University.

[3] Zhu GS, 2015, Current Situation and Countermeasures of Class Culture Construction in Colleges and Universities. East China Normal University.

[4] Fu CX, 2014, My Opinion on the Construction of Class Culture in Colleges and Universities. Science \& Technology Vision, (15): 67.

[5] Chen LR, 2014, Construction of Class Culture in Colleges and Universities - Taking Guangzhou Urban Construction Vocational College as an Example. Learning Weekly. 